\title{
Mobilities in the Labyrinth: Pressuring the Boundaries of Women's Careers
}

\author{
Aline Mendonça Fraga ${ }^{1}$ \\ SIDINEI ROCHA-DE-OLIVEIRA ${ }^{1}$
}

1 Universidade Federal do Rio Grande do Sul (UFRGS) / School of Administration, Graduate Program in AdMinistration, PORTO Alegre - RS, BRAZIL

\begin{abstract}
The contemporary world of work reveals a scenario formed by different contexts (global, society and culture, origin, and work) that highlight individual and collective career trajectories. All these contexts bring the historicity of gender constructions and are constituted by labyrinth mobilities that pressure the boundaries of women's careers. Considering the gap of studies that articulate career, mobility, and gender, this theoretical article argues that mobility, mainly geographic and social, may have reduced availability for women due to boundaries that engender immobility, anchored by sociocultural, political, organizational, and biological relationships. These are manifested by restrictions on freedom in some countries; family arrangements; expectations related to maternity and care activities of children and the elderly, which are socially attributed to women; by the organizational glass ceiling and the low representation in power positions. These immobilities lead to involuntary sedentarism, which imposes symbolic and labyrinthic barriers in their professional career. Labyrinth mobilities are disoriented from the traditional and safe path of traditional careers and uncertain about the steps for new career models. Careers are historical, dynamic, and in constant transformation, similar to what occurs with gender. The imperative of mobile careers and the (im)possibilities from the point of view of social markers of difference are prone for critical debates and for theoretical and empirical in-depth action exploring their limitations.
\end{abstract}

Keywords: Women. Mobility. Career. Gender.

\section{Mobilidades no labirinto: tensionando as fronteiras nas carreiras de mulheres}

\section{Resumo}

O mundo do trabalho contemporâneo se revela um cenário formado por diferentes contextos (global, de sociedade e cultura, de origem e de trabalho) que marcam trajetórias de carreira individuais e coletivas. Todos esses contextos trazem a historicidade das construções de gênero e constituem mobilidades no labirinto que tensionam fronteiras nas carreiras de mulheres. Considerando a lacuna de estudos que articulam carreira, mobilidade e gênero, este artigo teórico argumenta que a mobilidade, sobretudo geográfica e social, pode ter reduzida disponibilidade para mulheres, em razão de fronteiras que engendram pontos de imobilidade, ancorados por relações socioculturais, políticas, organizacionais e biológicas. Estas são manifestadas por: a) restrições à liberdade em alguns países; b) configurações familiares; c) expectativas relativas à maternidade e atividades de cuidado de crianças e pessoas idosas - socialmente atribuídas às mulheres; d) teto de vidro organizacional; e e) pouca representatividade em cargos de poder. A formação dessas imobilidades leva à produção de um sedentarismo, por vezes involuntário, que impõe barreiras simbólicas e vivenciadas em labirintos em sua trajetória profissional. Mobilidades no labirinto são desorientadas do caminho seguro das carreiras tradicionais, em termos de tempo e espaço, e incertas quanto às possibilidades nos novos modelos de carreira. Carreiras são campos históricos, dinâmicos e em processo de mudança, assim como gênero. O imperativo das carreiras móveis e as (im)possibilidades do ponto de vista dos marcadores sociais de diferença se mostram oportunos para debates críticos e um aprofundamento teórico e empírico quanto às suas limitações.

Palavras-chave: Mulheres. Mobilidade. Carreira. Gênero.

\section{Movilidad en el laberinto: tensando las fronteras en las carreras de las mujeres}

\section{Resumen}

El mundo del trabajo contemporáneo se revela un escenario formado por diferentes contextos (global, de la sociedad y la cultura, de origen y del trabajo) que destacan las carreras profesionales individuales y colectivas. Todos estos contextos traen la historicidad de las construcciones de género y constituyen movilidades en el laberinto que tensionan fronteras en las carreras de mujeres. Considerando la laguna de estudios que articulan carrera, movilidad y género, este artículo teórico argumenta que la movilidad, especialmente geográfica y social, puede tener reducida disponibilidad para mujeres en razón de fronteras que engendran puntos de inmovilidad, anclados por relaciones socioculturales, políticas, organizativas y biológicas. Estas se manifiestan por restricciones a la libertad en algunos países; configuraciones familiares; expectativas relativas a la maternidad y actividades de cuidado de niños y ancianos, atribuidas socialmente a las mujeres; por el techo de cristal organizativo y por la escasa representatividad en cargos de poder. La formación de estas inmovilizaciones conduce a la producción de un sedentarismo, a veces involuntario, que impone barreras simbólicas y vivenciadas en laberintos en su trayectoria profesional. Movilidades en laberintos son del camino tradicional y seguro de las carreras tradicionales, en cuestión de tiempo y espacio, y inciertas en cuanto a las posibilidades de los nuevos modelos de carrera. Las carreras son campos históricos, dinámicos y en proceso de cambio, así como género. El imperativo de las carreras móviles y las (im)posibilidades desde el punto de vista de los marcadores sociales de diferencia, son oportunos para debates críticos y profundización teórica y empírica en cuanto a sus limitaciones.

Palabras clave: Mujeres. Movilidad. Carrera. Género. 


\section{INTRODUCTION}

The first studies on careers portrayed the notion that social conditions influence the way professional opportunities are structured, regardless of one's agency capacity (ARTHUR, HALL and LAWRENCE, 1989). However, "careers are always careers in context" (MAYRHOFER, MEYER and STEYRER, 2007, p. 215), so it is essential to evaluate the elements that constitute the boundaries of a specific career.

A historical and situational comprehension allows exploring the circumstances in which organizations, societies, and people interact while observing the emergence of new professional arrangements. After the 1980s, movements such as business globalization, the digital revolution, and the feminization of the workforce, resulted in global companies and professionals, in the reduction of distances and borders between people and countries, and in the diversification of organizational spaces (MAYRHOFER, MEYER and STEYRER, 2007; INKSON, DRIES and ARNOLD, 2014).

These transformations changed the world of work at different levels. The world of work is a scenario formed by spheres with individual career paths at the center. The spheres are distinguished from each other by four main contexts: a) global; b) society and culture; c) origin; and d) work (MAYRHOFER, MEYER and STEYRER, 2007). Although gender is an issue discussed in the context 'society and culture' (MAYRHOFER, MEYER and STEYRER, 2007; COHEN, DUBERLEY and RAVISHANKAR, 2015), it is also present in others since both the context of the origin (ANDREWS and SHAHROKNI, 2014; FERNANDO and COHEN, 2014) and of work (including new configurations that emerge as a result of international mobility) (KEMP and RICKETT, 2018; RODRIGUEZ and SCURRY, 2019; SANG and CALVARD, 2019), reveal careers with distinct tasks and challenges for men and women. These contexts are marked by gendered historical constructions and the dynamics of mobility and immobility.

According to Andresen, Dickmann, and Suutari (2018), mobility has gained space in the discussion on global careers with an emphasis on studies focused on expatriation (BERRY and BELL, 2012; BARUCH, DICKMANN, ALTMAN et al., 2013; ROOS, 2013; RAMASWAMI, CARTER and DREHER, 2016) and migration (SANG, AL-DAJANI and ÖZBILGIN, 2013; ANDREWS and SHAHROKNI, 2014; RESSIA, STRACHAN and BAILEY, 2017; RIAÑO, 2016; SANG and CALVARD, 2019; TAPIA and ALBERTI, 2019). In the organizational space, there is an increasing appreciation of availability for mobility, which is an issue addressed in Brazilian studies focusing mainly on expatriate professionals (GONZÁLEZ and OLIVEIRA, 2011; GALLON, SCHEFFER and BITENCOURT, 2013; GALLON, FRAGA and ANTUNES, 2017; PRESTES, GRISCI and FRAGA, 2016). The relevance of the availability of mobility for career advancement form a scenario of 'involuntary nomadism' (GRISCI, CIGERZA, HOFMEISTER et al., 2006), where, according to Freitas (2009) mobility is a new indispensable symbolic capital in organizations and at work.

Apart from the discussion on expatriation - and, sometimes, migration -, which is based on the relationship between professionals and organizations, the debate on mobility is relevant, since not all movements are work-related (CRESSWELL, 2006; ELLIOTT and URRY, 2010; SHELLER, 2014a; CRESSWELL, DOROW and ROSEMAN, 2016). However, the imperative of professional mobility and the limitations and barriers imposed by social markers of difference - such as gender, race, class, or sexuality - are still little explored, both theoretically and empirically.

Thus, the growing discussion on gender differences in building international careers (FERNANDO and COHEN, 2014; COHEN, DUBERLEY and RAVISHANKAR, 2015; KEMP and RICKETT, 2018; RODRIGUEZ and SCURRY, 2019; SANG and CALVARD, 2019), has evidenced that societies, organizations, and careers are structured in gendered contexts. Also, there is a gap in studies that connect career, mobility, and gender (referring mainly to women). This essay, therefore, argues that women may be less available for mobility due to boundaries anchored in socio-cultural, political, organizational, and biological relationships.

These boundaries are manifested by restrictions on freedom (FERNANDO and COHEN, 2014; COHEN, DUBERLEY and RAVISHANKAR, 2015; KEMP and RICKETT, 2018) in some countries, and by the reaffirmation of privileges in others (RODRIGUEZ and SCURRY, 2019). Other examples of boundaries are family settings, expectations related to motherhood and care activities for children and the elderly - which are socially attributed to women -, the organizational glass ceiling and the low representation in leadership positions. The construction of boundaries based on limitations of the context causes tensions from the local to the global context. Looking at mobility from a gender perspective is a topic worth studying given that all forms of movement imply freedoms and restrictions. The discussions about career, mobility, and gender allow advancing and deepening reflections through the interrelationships between concepts. 
This study is presented as a theoretical essay (MENEGHETTI, 2011) and follows these discussions based on three sections: a) gender and work; b) careers in context; and c) mobility as a way of being and working. The first introduces the main guiding concepts forming the theoretical framework - considering that there are different currents to address gender and career, as well as extensive literature on the topic (FRAGA, GEMELLI and ROCHA-DE-OLIVEIRA, 2019). The second section aims to connect the concepts, debating different aspects of women's mobility and immobility in the construction of careers. Finally, the study presents potential paths to continue the discussion and build a research agenda, seeking to expand research and debates on the topic in Brazil.

\section{GENDER AND WORK: CONNECTING CONTEXTS AND CONCEPTS}

Organizational studies have analyzed the gender issue both at the international level (MCKIE, BIESE and JYRKINEN, 2013; FERNANDO and COHEN, 2014; LEUZE and STRAUß, 2016; KOSSEK, SU and WU, 2017) and the national level (SOUZA, CORVINO and LOPES, 2013; SOUZA, BIANCO and JUNQUILHO, 2015; HRYNIEWICZ and VIANNA, 2018). Given the sexual segregation of work (HIRATA, 2018) and gender pay gap (IBGE, 2018; IPEA, 2019), 'gender' as a category of analysis continues to ignite heated debates in the field.

In her first theorizations on the theme, Scott (1986) warns that, apart from biological issues, gender indicates cultural construction. The idea is that socially created concepts instructed the appropriate roles for men and women, describing "a social category imposed on a sexed body" (SCOTT, 1986, p. 1056) or the social construction of sexual difference. Gender, therefore, is a form of social distinction marked by power relations and constitutes meanings based on the differences between bodies. In a later study, Scott (2012) clarifies that understanding gender as more than a mere guide to how men and women are defined in a relational way, allows visions of social order to be "challenged, overrun, repelled, and defended regarding the definitions of male or female" (SCOTT, 2012, p. 347, our translation). Thus, it is possible to explore paths to new visions and perspectives regarding the societies' diversity, based on cultural, social, and political historicity.

Recognizing that gender implies social relationships and sexual difference marked by structures of power is an opportunity to expand the existing notions and discuss them collectively. Studies on women in organizations analyze the concept of the "glass ceiling" (EZZEDEEN, BUDWORTH and BAKER, 2015). From a predominantly liberal perspective that claims equality for men and women when seeking leading positions in their careers (SOUZA, CORVINO and LOPES, 2013), the 'glass ceiling' represents an invisible barrier for women, jeopardizing their professional advancement. The studies refer to a woman who takes or is willing to take on managerial positions, and they seek to debate possible sexual equity in organizations (LIMA, CARVALHO NETO, LIMA et al., 2014).

The metaphor of the 'glass ceiling' emerged in the mid-1980s. Despite being quite common, Eagly and Carli (2007) argue that the image of the glass ceiling is too rigid to explain the permeability of barriers experienced by women after the 2000 s. The authors address the theme of leadership and indirect access to positions of power, starting with the physical barriers imposed on women until the beginning of the twentieth century. They discuss the barriers reflected in the concept of the glass ceiling after the feminization of the post-war workforce and, finally, the authors approach the current notion of diffuse labyrinths. According to this metaphor, prejudices and discrimination that block women's paths have not disappeared but are presented as labyrinths.

The discussion on the social hierarchy of inequality, reflected in the gender issue, loses its strength when it involves aspects of sexuality, sexual orientation, ethnicity, disability, and nationality (HIRATA, 2018). There is a persistent contradiction in this inequality - be it in the scope of domestic work, in the professional hierarchy, or in political representativeness - since the most updated data show that women are better educated than men in almost all levels of schooling (HIRATA, 2018; IBGE, 2018).

In Brazil, research in organizations are very close to liberal feminism, which is an a-historical perspective of women, focused on their profile as executives (SOUZA, CORVINO and LOPES, 2013). By affirming universal values - as manifested in the American feminist movement - this research reinforces the interests of white, heterosexual, and middle/upper-class women 
(HRYNIEWICZ and VIANNA, 2018). Therefore, disseminated and validated by the organizational discourse (and, in many cases, by the women themselves), it does not discuss and/or problematize the need to advance in the debate on gender relations in workplaces and organizations.

International studies, such as Knight's (2016) research on black Caribbean female entrepreneurs, opened the debate for expanding opportunities for women when they own companies. McKie, Biese and Jyrkinen (2013) observed the dimensions of control of space and time to avoid gender obstacles in organizations, the flexibility to monitor the family, and the autonomy to determine key aspects of the career, as essential elements of the scenario of Scottish and Finnish women who decided to open their own businesses. Fernando and Cohen (2014), in a study with so-called "highly qualified" women from Sri Lanka, observed that female respectability (a construct gendered and institutionalized during the nineteenth and twentieth centuries) is guided by conducts for maintaining a good reputation and is still decisive for women's agency capacity and career advancement.

As for mobility, women are at a disadvantage and face restrictions (COHEN, DUBERLEY and RAVISHANKAR, 2015; KEMP and RICKETT, 2018; RODRIGUEZ and SCURRY, 2019; SANG and CALVARD, 2019). There is apparent gender neutrality when it comes to qualified professionals, especially for geographic mobility, whether through migration or expatriation (voluntary or organizational). However, the data shows that these movements are dominated by men (ROSS, 2013; FESTING, KNAPPERT and KORNAU, 2015).

Thus, the mobility that women experience in the 'labyrinth' pressures the boundaries around their careers. Two intertwining points stand out: a) mobility as a central element in building and discussing careers; and b) the relevance of the debate on the imperative of mobile careers and the (im)possibilities from the point of view of social markers of difference.

\section{CAREERS IN CONTEXT: FROM PERSONAL CAREER PATHS TO THE GLOBAL CONTEXT}

The development of the concept of career encompasses different understandings about socioeconomic structures, characteristics of the labor market, values, culture, and the historical context in which organizations operate, and people interact. Therefore, the scenario changes, as these elements change (SULLIVAN and BARUCH, 2009). Careers can take place inside and outside organizations and are shaped by people's actions and the context in which they live and work. According to Mayrhofer, Meyer, and Steyrer (2007, p. 216), "however, in theoretical as well as empirical research, there is a dominance of models and studies using frameworks that implicitly or explicitly underline an individual-centered perspective." This individual, male or female, would have full autonomy to direct their professional choices and adapt to all changes that arise on their path.

This understanding of the individual gained ground with the career models that emerged mainly in the 1990s. The promotion of the 'Western-style' of individualism and proactive professional behavior (INKSON, DRIES and ARNOLD, 2014), or the opening of other options beyond the limits of the organization (ARTHUR, 1994) marked the period. The concepts of 'boundaryless career' (ARTHUR, 1994) and 'protean career' (HALL, 1996) emerged to oppose the traditional model. They point to a future of unlimited professional arrangements, regardless of a single organization. Barriers established by vertical growth would no longer be a limiting factor for professional development. Stable employment would be replaced by a new dynamic, in which individuals control their professional future without depending on organizational frameworks (HALL, 1996; INKSON, GUNZ, GANESH et al., 2012).

Sullivan and Arthur (2006) added conditional elements for paths and possibilities in the boundaryless career model, such as psychological and physical aspects related to skills, gender (used to refer to women, in this case), culture, and individual differences. For the authors, women are more prone to psychological mobility than to physical mobility because they are more influenced by family issues (husband and children) when making career decisions. Leuze and Strauß (2016) warn that more than mere choice, these decisions are the result of gendered socialization processes and social and cultural norms that identify women as responsible for the care of the home and children.

Although these career theories address mobility, they do not particularly include geographic mobility, expatriation, or migration. The spread of international business, especially from Western companies to other regions of the world, 
has created a more diverse and multicultural environment. Global careers and professional mobility are the results of this process - thus, businesses operating worldwide build careers regardless of their geographic location (INKSON, DRIES and ARNOLD, 2014).

Immigrants can also be considered in the context of mobility. For the literature on management, however, they are different from organizational or voluntarily expatriates because immigrants leave their country regardless of organizational ties, but for economic reasons (GONZÁLEZ and OLIVEIRA, 2011). Studies on immigrants' careers are still incipient, but they point to the phenomenon of "marginalized elites," that is, highly qualified professionals who do not have the same professional prestige when they migrate and seek work abroad (SANG, AL-DAJANI and ÖZBILGIN, 2013; COHEN, DUBERLEY and RAVISHANKAR, 2015; RIAÑO, 2016; TAPIA and ALBERTI, 2019). In addition, these studies indicate the reproduction of gender and race privileges in the mobility process of white men (SANG and CALVARD, 2019).

The kaleidoscope career model highlights the relationship between career and gender and proposes encompassing the complexities inherent to women's careers (SULLIVAN and MAINIERO, 2008; MAINIERO and GIBSON, 2018). Based on the notion of the kaleidoscope that uses three mirrors and forms unlimited color patterns, the model combines the parameters authenticity, balance, and challenge, in order to reflect unique patterns in the careers of women. Sullivan and Mainiero (2008) consider that women face more obstacles at work - even with a high educational level, they are the minority in management positions - and tend to accumulate extra-organizational activities more than men. O'Neill and Jepsen (2019) expand this discussion, presenting a model that points out how mobility limitations are reaffirmed when women are considered responsible for caring for children, the elderly, and the sick. The parameters of the kaleidoscopic career are different for women who take responsibility for the care of family members, an activity that is often unpaid and socially constructed as a female role. This context becomes another element of immobility, another challenge or barrier in the intricate professional labyrinth since many workers are forced to leave their professional activities to exclusively dedicate to care.

For Chanlat (1995), careers are socially rooted, marked by the country or regional contexts. Mayrhofer, Meyer, and Steyrer (2007) adopted another point of view, but also sought to overcome the excessive focus on individual action. They highlight the importance of contexts, presented at four levels: a) global; b) society and culture; c) origin; and d) work. The world of work is influenced by the economic and institutional environment, foreign markets, and new organizational forms, ways of working, and social relations. Other studies highlight the contributions from international markets for career changes, examining topics such as segmentation of the world of work (BUSER, NIEDERLE and OOSTERBEEK, 2014; LEUZE and STRAUß, 2016), mobility and migration (COHEN, DUBERLEY and RAVISHANKAR, 2015; RESSIA, STRACHAN and BAILEY, 2017; WALTER, 2015), and new work configurations influencing the way people experience their career - boundaryless career and protean career, for example (BARUCH and REIS, 2016; PORTER, WOO and TAK, 2016).

Regarding the context of origin, Mayrhofer, Meyer and Steyrer (2007) consider that class and social origin, as well as economic conditions, gender, and ethnicity, strongly influence the capacity for professional mobility. It is common for people to maintain an economic level close to that of their families of origin. In this case, the propensity to mobility is understood as the possibility of progressing professionally and financially.

In the context of society and culture, themes such as the gendering of workspaces (STOKES, 2017), sexual roles, and gender structure (RISMAN and DAVIS, 2013), gender reproduction in careers historically occupied by women (TROTTER, 2017), and discussions on the queer theory for occupational segregation (MCDONALD, 2016) point to potential paths in research. Brazilian studies also broaden the discussion of gender and sexuality using queer and masculinities approach (CARRIERI, SOUZA and AGUIAR, 2014; SOUZA, BIANCO and JUNQUILHO, 2015; SOUZA, 2017).

Finally, in the global context, the internationalization of companies stands out, a phenomenon that created the organizational need for global careers, expanding job opportunities beyond the limits of national borders. These studies highlight research on expatriation and repatriation seeking, above all, to analyze the characteristics of global managers and practices of international human resources (BARUCH, DICKMANN, ALTMAN et al., 2013; RAMASWAMI, CARTER and DREHER, 2016). 


\section{MOBILITY AS A WAY OF BEING AND WORKING}

Mobility as a way of life can be viewed as a new symbolic capital in contemporary times. It influences and composes different spheres of life (individual, organizational, or social), reaching a desirable and expected value of all and by all (FREITAS, 2009). For Freitas (2009), mobility is a prescription that characterizes this moment in history, a moment of transformations, inconsistencies, and uncertainties that demand speed, agility, and flexibility.

Cresswell $(2006,2010,2012)$ understands that mobility carries meanings that circulate throughout the modern western world. In general, mobility is linked to the ideas of advancement, freedom, and opportunity. It can also be understood as deviation and resistance. In this essay, the heart of the debate is found in 2 forms of mobility: a) geographic, which gains new contours today, and represents a status that differentiates workers and stands out in the construction of global careers; and b) social, usually connected to the stratification of society and present in traditional career models, which are based on vertical promotion within the company's hierarchy.

Geographic mobility converges with growing trends - resulting from emblematic economic, social, and cultural changes such as intense consumerism, mobile technologies, and climate change, which accelerate the circulation of people, ideas, and objects (CRESSWELL, 2010; ELLIOTT and URRY, 2010).

In the sociological tradition, mobility refers to class mobility, i.e., the movement of social groups in the socioeconomic hierarchy. Class is defined by the set of economic and social attributes, based on their social value and how they are reflected in everyday practices (BOURDIEU, 2007). Classes are not defined solely by ownership (such as capital volume or structure) or belonging to a particular group (sex, age, social, or ethnic origin), but also by the way capital volume and structure shape and value determinations that social markers (sex, race, or age) impose by practices.

Space, in this case, is a vacuum where social processes occur, and geographical movements (producing new capital capable of generating distinction between workers) can also indicate social mobility (SHELLER, 2014a, 2014b). The new interdisciplinary field addressing the issue of mobility includes movements of people, animals, and objects, as well as information, images, and money. Also, it includes physical means around movement, such as infrastructure, information systems, and vehicles.

For Cresswell (2006), human mobility can be understood as a socially produced movement occurred in 3 relational moments: a) first, mobility measured and analyzed by models, migration theories, and urban traffic managers; b) second, the representation of ideas and meanings ranging from films to laws, from medicine to photography, from literature to philosophy; and c) third, the practical and experiential way of being in the world, directly related to the body.

Elliott and Urry (2010) consider that mobility is expressly linked to immobility, as it is only possible to move because other people remain immobile, regardless of whether they are personal assistants who organize travels, housekeepers, children and family members of workers of assembly lines that manufacture cell phones and other technological equipment. For this reason, mobility is not for everyone and cannot be. It is noteworthy that questions about the social markers of difference - such as (im)mobility linked to race, gender, class, and sexual orientation - were neglected in this new phase of mobility research.

Regarding the career perspective, Feldman and $\mathrm{Ng}$ (2007) connect mobility and entrenchment (or, immobility) in a different way from Chanlat (1995), who focused on the social construction of careers as a way of entrenchment. The authors consider that both concepts can indicate different levels and ways of being "mobile" or "immobile." In the organizational scope, this relationship can occur due to change or permanence in employment, company, or occupation. However, the process of appreciating mobility begins in school education and continues in higher education. Schools and universities encourage young people to have experiences outside their home cities - preferably outside the country-before entering the labor market. Thus, the world of work values careers that entail mobility, in which the world becomes the space for action. These careers attract mainly young people, due to the idea of freedom, even if the salaries offered are not higher than those paid in the "immobile" (in this case, national) version of the same activity. It is noteworthy, however, that the concept of career entrenchment is related to occupational permanence and appears in opposition to the boundaryless career. Thus, the discussion focuses more on the forces that keep someone in an organization, based mainly on individual choice (HOWES and GOODMAN-DELAHUNTY, 2015). Entrenchment is, therefore, more distant from the contextual and collective discussion on mobility and immobility and is closer to a counterpoint to boundaryless career. 
According to Freitas (2009), mobility, nomad, traveler, and sedentary are concepts and understandings of a way of life. They are concepts that overlap and connect. In the modern version, the nomadic person - who historically, was part of a group that moved from place to place with all their belongings and family members to 'live the path' and prepare their trip for the next destination - is the individual, woman or man, and their family, moving without the group or understanding that the group is the organizational unit to which they belong. The sedentary person or group, on the other hand, is who - in their place of origin or not - settle permanently or for a long period in a specific geographic location.

Mobility in the organizational context is an individual capital, a new basis for supporting nomadism that aligns well with the expectations of companies, as they are looking for people who do not stay still, who are always involved in "a desire, a will, a project of their own to always change, to always learn, to seek the new, to always know" (FREITAS, 2009 , p. 257, our translation). This world of work without boundaries is related to the ways of thinking about the professional path observed near the turn of the twentieth century, especially in the utopian ideal of a boundaryless career (BARUCH and REIS, 2016)

Grisci, Cigerza, Hofmeister et al. (2006) emphasized the emergence of involuntary nomadism, more strongly linked to the paths of men, required of banking professionals as one of the effects of productive restructuring. Mobility strengthens a carefree organizational behavior regarding the repercussions of its imperative in human life, since those who do not move, do not advance. This result converges with the way of experiencing a career as a whole in modernity, with a focus on mobility, as announced by the boundaryless career model. However, it is worth questioning the extent to which a mobile career is available to all, particularly women, given the conditions in labyrinths permeated by immobility/sedentarism that they face throughout their paths.

The imperative of mobility in the new work configurations becomes another element of differentiation in the world of work, recognized in specific forms of movement. Expatriates, for example, differ from immigrants and refugees, although international geographical mobility is present in the three groups. Likewise, mobility implies different meanings according to gender, race, ethnicity, or age, and the organizational link of those who move. The idea of boundaryless career as a new limit (or end of the limits) of professional growth becomes yet another form of social (im)mobility. The new mobility also represents a movement of research to look at societies, especially in the areas of human and social sciences (CRESSWELL, DOROW and ROSEMAN, 2016) and the construction of places and non-places, in constant movement, oscillating between cycles of historical repetition and transformations.

\section{MOBILITY IN THE WORK LABYRINTH: PRESSURING THE BOUNDARIES OF WOMEN'S CAREERS}

The discussions on career, gender, and mobility allow advancing and deepening reflections based on the interrelationships established among the concepts. There are three elements worth highlighting in this essay: mobility as a central element in the construction and discussion of careers; the labyrinth built around women's careers; and how the boundaries of this labyrinth emerge in the process of forming and limiting new spaces of action considering the restrictions imposed by the context.

\section{MOBILITY AS A CENTRAL ELEMENT OF CAREER DISCUSSION}

Mobility is a central aspect in career discussion, starting with the understanding of a career limited to the organizational space, when mobility is linked, preferably, to upward movements (sometimes also downward) of a professional path. First, at the height of the Fordism, mobility was an internal phenomenon, occurring through periodic promotions within the same organization (HALL, 1976). Subsequently, the growth of the narrative around employability and the horizontalization of organizations opened space for mobility among companies, based on differentiation and more intense professional development. The discussion about models such as boundaryless career (ARTHUR, 1994) and protean career (HALL, 1996) emerged in this context. Therefore, mobility becomes an individual imperative for professional advancement. 
In addition to the organizational space, career mobility can be linked to professional advancement (social mobility), or moving around cities, regions, or countries (geographical mobility). Social mobility is a typical topic in the discussion of the sociology of work, but the geographical mobility is the element that stands out, expressed in the discussion of international careers (BERRY and BELL, 2012; BARUCH, DICKMANN, ALTMAN et al., 2013; ROOS, 2013; RAMASWAMI, CARTER and DREHER, 2016). It gains relevance with the globalization of markets, the expansion of the number of multinational companies, and the discourse of boundaryless carrer (BARUCH and REIS, 2016; PORTER, WOO and TAK, 2016).

Despite the 'glamour' of international or global careers, geographic mobility usually only represents a period during the professional path, with results that are highly challenged, considering the indications of professional stagnation after repatriation (FREITAS, 2009; GALLON, SCHEFFER and BITENCOURT, 2013; PRESTES, GRISCI and FRAGA, 2016). In addition, career mobility is a source of distinction among workers (BERRY and BELL, 2012). Studies on international mobility show that women often renounce their personal mobility because of their husbands' career paths. Also, they are subject of migratory policies that prevent them from working when following their husband's mobility, which leads to professional breaks and anticipating negative professional impacts (ROOS, 2013; EVERTSSON, GRUNOW and AISENBREY, 2015). When a man relocates due to his wife's work, it is unusual for him to stop working (FESTING, KNAPPERT and KORNAU, 2015; FRAGA, ANTUNES and ROCHA-DE-OLIVEIRA, 2020).

\section{THE LABYRINTH AROUND WOMEN'S CAREERS}

Amid the growth of global careers, mobility is an important dimension for the understanding of professional paths. However, these new career reconfigurations build spaces of distinction and barriers that need analysis and debate. The logic that encompasses the understanding of mobile and immobile has an interface linked to gender: "the sperm's mobility is coded as masculine and active, while the egg is passive, relatively immobile, and feminine" (CRESSWELL, 2006, p. 8). Thus, "meanings given to mobility inside the human body - meanings with highly gendered connotations - are being translated into the politics of the space race [referring to the dispute between the US and the Soviet Union space programs]. Mobility, here at least, means masculinity" (CRESSWELL, 2006, p. 9).

Although not directly addressing the issue of mobility, but discussing domination, Bourdieu (2004), pointed out the strength of this masculine order, which is introduced as neutral and is present throughout the social world, with support from medical sciences, as an immense symbolic machine that seeks the division of labor in homes and in other living spaces. The patriarchal ordering of society shaped the identity of women linked to the home, household chores, and care activities. This order, which links women to the domestic space, has also limited their opportunities and mobility in the job market, both socially and geographically, either because of less access to managerial positions or because they are neglected in expatriation processes. These different barriers and limitations form paths in the labyrinth of women's careers, marked by advances and setbacks, periods of growth and decline.

Gender is historical, produced in time and space. The key to production, reproduction, and contestation of gender is found in the dialectics of fixity and flow (UTENG and CRESSWELL, 2008), immobility and mobility (ELLIOTT and URRY, 2010), sedentarism and nomadism (FREITAS, 2009). "Narratives of mobility and immobility play a central role in the constitution of gender as a social and cultural construct" (UTENG and CRESSWELL, 2008, p. 2), starting with the binary form of male-female, man-woman, as pointed out in the first feminist theories (CALÁS and SMIRCICH, 1999) and representations of how, where, and how fast and often people move (UTENG and CRESSWELL, 2008).

Although geographical mobility is evidenced within the limits of career paths, social mobility is also affected since many women renounce their possibilities of professional advancement. Prasad, D'Abate and Prasad (2007) highlight the difficulties of some groups considered socially marginalized - which include, in addition to women, people of different ethnic-racial origins and religions - to act and develop professionally in certain areas and dimensions of work. This limitation is reproduced in the possibilities of expatriation and migration since women have fewer mobility opportunities. Therefore, the limitations of social and geographic mobility are two dimensions that restrict women's careers.

It is worth noting that the boundaries of the labyrinth around women's careers have been under pressure by recent socioeconomic and political changes. In Brazil, women are the majority in vocational and higher education (INEP, 2019) 
and have achieved new job positions, both driven by female entrepreneurship (MACHADO, GUEDES and GAZOLA, 2017) and provided by advances in technologies, like virtual work. Despite the criticisms related to job insecurity, the sharing economy also made flexible contracts, part-time work shifts, and alternative professional paths that can benefit women in balancing career and care activities. Finally, the diversity policies in organizations that are promoting the debate on gender equity stand out, both in Brazil (HENDERSON, DE ARAÚJO FERREIRA and DUTRA 2016) and internationally (KÖLLEN, 2019), including the issue of the various possible experiences - gender intersections, sexuality, and race - for example, within the management of diversity (DENNISSEN, BENSCHOP and VAN DEN BRINK, 2020).

\section{LABYRINTHS UNDER CONSTRUCTION: RESTRICTIONS AND BUILDING NEW WORKING SPACES}

The points of immobility, limits, and boundaries of professional labyrinths are built and anchored by sociocultural, political, organizational, and biological relationships. These are manifested by a) restrictions on freedom in some countries; b) family settings; c) expectations related to maternity and care activities for children and the elderly (socially attributed to women); d) organizational glass ceiling; and e) little representation in positions of power.

The process of building such immobility leads to the production of a sedentary lifestyle, sometimes involuntary, that imposes symbolic barriers, considering the uncertainties based on the possibilities of kaleidoscopic careers (SULLIVAN and MAINIERO, 2008; MAINIERO and GIBSON, 2018), boundaryless careers (ARTHUR, 1994; INKSON, GUNZ, GANESH et al., 2012; BARUCH and REIS, 2016), or protean careers (HALL, 1996; PORTER, WOO and TAK, 2016), since the male and female models are represented in opposition. Mobilities - interrupted, expanded, redirected by the limits of the social markers, particularly gender - form a labyrinth and contradict the idea of social mobility and upward career, marked by temporal and spatial advances also related to age.

It is worth mentioning that some social limitations in certain societies can result in the construction of new occupational mobilities. Andrews and Shahrokni (2014) state that, especially in the 1980s and 1990s, women started to become mobile in the so-called "developed world," whereas in other places, such as in Iran and Mexico, mobility occurred precisely because national institutions have created measures to exclude or segregate women. The ethnographic research subsidizing their essay observed the patriarchal practices and organizations that reinforced gender differences and male dominance, while creating arrangements that adapted patterns of masculinity and femininity, aligned with the global economic pressure. In this sense, these organizations opened space for women to work, study, consume, and, consequently, allowed mobility.

Despite these notes, the literature deals predominantly with career capital as something gender-neutral, or at least, gender issues are not explicitly addressed. Theories of boundaryless career and protean career are challenged when analyzing the professional experiences of women, ethnic or minoritized groups. The theories' fundamental conceptions, such as freedom from barriers, individual will, and minimal influence of social structures, can be completely questioned in these cases. Finally, against the path dictated by nomadism, there is the construction of an involuntary sedentary lifestyle in the women's careers, due to the manifestations of immobility in education and the restriction of new spaces of action, based on historical and contextual limitations.

\section{CONCLUSION AND RESEARCH AGENDA}

The issue of careers sheds light on the significant roles of the contexts in shaping the individuals' agency capacity. Among the contexts observed by Mayrhofer, Meyer, and Steyrer (2007), this essay highlights 'society and culture' (gender, community, ethnicity, and demography) and 'origin' (social class, current life situation, work history, and socialization of education). These contexts have a strong influence on building women's advantages or disadvantages regarding the freedom of professional choices, as well as being at the foundations of the involuntary (im)mobility.

This essay highlighted the restrictions of mobility due to boundaries that create points of immobility, anchored by sociocultural, political, organizational, and biological interweaving that influence the careers of women. Despite the symbolic capital of mobility, its influence in careers enable criticisms and theoretical and empirical deepening, considering the segmentation and restriction of rights and freedoms that sustain immobility, limits, and barriers. 
To the extent that careers always occur in certain contexts (MAYRHOFER, MEYER and STEYRER, 2007), it is essential to understand the elements that mark the analytical space in which they operate and the elements that mark the paths, without perceiving individual actions in an occupational vacuum (SULLIVAN and BARUCH, 2009). Mobilities (particularly geographic and social) add other social constructions of difference and inequality besides gender, such as class, race, sexuality, disability, nationality, and religion. They intervene in the paths and intertwine in the understanding of career contexts. The historical contextualization of the collective and individual field reveals particular intersections regarding careers. Thus, to advance the discussion on mobility and career considering such social inequalities, it is necessary to take an intersectional approach.

It is considered that, in different contexts, social relations and their dynamism reveal more than fixed categories and expose that there is no hierarchy of types of oppression (HIRATA, 2018). Intersectionality, a term coined by black feminism, represents the idea that social identities are always experienced simultaneously, and that privilege and inequality are not reducible to just one axis of difference (MCDONALD, 2016). The look at intersectionality implies deconstructing broad analytical categories. It exposes differences and similarities among groups. Furthermore, it demands considering the existence of social groups that are sometimes invisible and studying broad relations of power, privilege, and inequality among them.

Expatriation and immigration, for example, are related to geographical mobility. However, the first is linked to new challenges and possibilities for professional growth, whereas the latter - which is rarely examined in studies discussing careers - reflects a situation where disadvantaged people move to other countries in search of work or motivated by professional opportunities. The large companies that offer professional growth through expatriation to some workers, may be the same organizations that hire immigrants who, mainly due to low schooling, are placed in lower positions (BERRY and BELL, 2012). These mobilities reveal hierarchies and inequalities among professionals in the same work environment, which includes gender and other elements worth analyzing such as race, ethnicity, age, nationality, culture, and economic and social conditions. It is not only because of low qualification that the segmentation and precarization of work occurs.

Thus, an intersectional analysis focused on the careers' geographical and social mobility contributes to understanding how social constructions of difference integrate and combine in to create different levels of freedom for movement, forming labyrinths with islands of compulsory inactivity and nomadism for certain social groups. According to Hirata (2018, p. 19, our translation), "gender contains the dimension 'sexuality' and, therefore, intersectionality must point to the overlap of gender/sexuality, race, and class." The following research agenda is suggested:

a) Address the relationships of (im)mobility in occupational fields where there is a historical predominance of women or men, revealing privileges and disadvantages;

b) Discuss the connection between mobility and the social stratification that is built in common workspaces for different social groups, such as immigrants, refugees, and expatriates;

c) Address the new dynamics of occupational mobility and virtualization and the creation of exclusive or inclusive workspaces in relation to the intersectionality of gender, sexuality, class, race/ethnicity, disability, nationality, age, and others;

d) Analyze the hierarchies of opportunities for men in traditionally female professions produced by the glass escalator (ORUPABO and NADIM, 2019);

e) Explore the relationships between mobility, gender, and sexuality in careers, intersected with social class; and

f) Explore mobilities motivated by diverse issues such as relationships, care activities, health, religiosity, and social/ political activism and their impact on labor relations.

\section{ACKNOWLEDGMENTS}

The authors thank the kind support of the Coordination for the Improvement of Higher Education Personnel (CAPES). 


\section{REFERENCES}

ANDRESEN, M.; DICKMANN, M.; SUUTARI, V. Typologies of internationally mobile employees. In: DICKMAN, M.; SUUTARI, V.; WURTZ, O. (Org.). The management of global careers: exploring the rise of international work. London: Palgrave Macmillan, 2018. p. 33-61.

ANDREWS, A.; SHAHROKNI, N. Patriarchal accommodations: women's mobility and policies of gender difference from urban Iran to migrant Mexico. Journal of Contemporary Ethnography, v. 43, n. 2, p. 148175, 2014.

ARTHUR, M. B. The boundaryless career: A new perspective for organizational inquiry. Journal of Organizational Behavior, v. 15, n. 4, p. 295-306, 1994.

ARTHUR, M. B.; HALL, D. T.; LAWRENCE, B. S. Generating new directions in career theory. In: ARTHUR, M. B.; HALL, D. T.; LAWRENCE, B. S. (Eds.). Handbook of career theory. Cambridge: Cambridge University Press, 1989. p. 7-25.

BARUCH, Y.; REIS, C. How global are boundaryless careers and how boundaryless are global careers? Challenges and a theoretical perspective. Thunderbird International Business Review, v. 58, n. 1, p. 13-27, 2016.

BARUCH, Y. et al. Exploring international work: types and dimensions of global careers. The International Journal of Human Resource Management, v. 24, n. 12, p. 2369-2393, 2013.

BERRY, D. P.; BELL, M. P. Expatriates: gender, race and class distinctions in international management. Gender, Work \& Organization, v. 19, n. 1, p. 10-28, 2012.

BOURDIEU, P. A dominação masculina. 4. ed. Rio de Janeiro: Bertrand Brasil, 2004.

BOURDIEU, P. A distinção: crítica social do julgamento. Porto Alegre: Zouk, 2007.

BUSER, T.; NIEDERLE, M.; OOSTERBEEK, H. Gender, competitiveness, and career choices. The Quarterly Journal of Economics, v. 129, n. 3, p. 1409-1447, 2014.

CALÁS, M. B.; SMIRCICH, L. Do ponto de vista da mulher: abordagens feministas em estudos organizacionais. In: CLEGG, S.; HARDY, C.; NORD, W. (Orgs.). Handbook de estudos organizacionais: modelos de análises e novas questões em estudos organizacionais. São Paulo: Atlas, 1999. p. 275-329.

CARRIERI, A. de P.; SOUZA, E. M. de; AGUIAR, A. R. Camillo. Trabalho, violência e sexualidade: estudo de lésbicas, travestis e transexuais. Revista de Administração Contemporânea, v. 18, n. 1, p. 78-95, 2014.

CHANLAT, J. F. Quais carreiras e para qual sociedade?(I). Revista de administração de Empresas, v. 35, n. 6, p. 67-75, 1995.

COHEN, L.; DUBERLEY, J.; RAVISHANKAR, M. N. Examining the interplay of career, migration and national cultural identity: the case of Indian scientists. International Migration, v. 53, n. 5, p. 104-121, 2015.

CRESSWELL, T. On the move: mobility in the modern Western world. New York: Routledge, 2006.

CRESSWELL, T. Mobilities I: catching up. Progress in Human Geography, v. 35, n. 4, p. 550-558, 2010.
CRESSWELL, T. Mobilities II: still. Progress in Human Geography, v. 36, n. 5, p. 645-653, 2012.

CRESSWELL, T.; DOROW, S.; ROSEMAN, S. Putting mobility theory to work: conceptualizing employment-related geographical mobility. Environment and Planning A: Economy and Space, v. 48, n. 9, p. 1787-1803, 2016.

DENNISSEN, M.; BENSCHOP, Y.; VAN DEN BRINK, M. Rethinking diversity management: an intersectional analysis of diversity networks. Organization Studies, v. 41, n. 2, p. 219-240, 2020.

EAGLY, A. H.; CARLI, L. L. Through the labyrinth: the truth about how women become leaders. Boston: Harvard Business Press, 2007.

ELLIOTT, A.; URRY, J. Mobile lives. New York: Routledge, 2010.

EVERTSSON, M.; GRUNOW, D.; AISENBREY, S. Work interruptions and young women's career prospects in Germany, Sweden and the US. Work, Employment \& Society, n. 26, p. 1-18, 2015.

EZZEDEEN, S. R.; BUDWORTH, M. H.; BAKER, S. D. The glass ceiling and executive careers: still an issue for pre-career women. Journal of Career Development, v. 42, n. 5, p. 355-369, 2015.

FELDMAN, D. C.; NG, T. W. Careers: mobility, embeddedness, and success. Journal of Management, v. 33, n. 3, p. 350-377, 2007.

FERNANDO, W. D. A.; COHEN, L. Respectable femininity and career agency: exploring paradoxical imperatives. Gender, Work \& Organization, v. 21, n. 2, p. 149-164, 2014.

FESTING, M.; KNAPPERT, L.; KORNAU, A. Gender-specific preferences in global performance management: an empirical study of male and female managers in a multinational context. Human Resource Management, v. 54, n. 1, p. 55-79, 2015.

FRAGA, A. M.; ANTUNES, E. D. D.; ROCHA-DE-OLIVEIRA, S. The Female and the Male Professional: Gender, Career and Expatriation Interfaces in Trajectory for Female Expatriates. BBR. Brazilian Business Review, v. 17, n. 2, p. 192-210, 2020.

FRAGA, A. M.; GEMELLI, C. E.; ROCHA-DE-OLIVEIRA, S. Cenário das publicações científicas em carreira e gênero. Revista Pensamento Contemporâneo em Administração, v. 13, n. 3, p. 158-178, 2019.

FREITAS, M. E. D. A mobilidade como novo capital simbólico nas organizações ou sejamos nômades? Organizações \& Sociedade, v. 16, n. 49, p. 247-264, 2009.

GALLON, S.; FRAGA, A. M.; ANTUNES, E. D. D. Conceitos e configurações de expatriados na internacionalização empresarial. Revista Eletrônica de Administração, n. 23, p. 29-59, 2017.

GALLON, S.; SCHEFFER, A. B. B.; BITENCOURT, B. M. "Eu fui, voltei e ninguém viu": um estudo sobre a expectativa de carreira após a repatriação em uma empresa brasileira. Cadernos EBAPE.BR, Rio de Janeiro, v. 11, n. 1, p. 128-148, 2013.

GONZÁLEZ, J. M. R.; OLIVEIRA, J. A. Os efeitos da expatriação sobre a identidade: estudo de caso. Cadernos EBAPE.BR, Rio de Janeiro, v. 9, n. 4, p. 1122-1135, 2011.

GRISCI, C. L. I. et al. Nomadismo involuntário na reestruturação produtiva do trabalho bancário. Revista de Administração de Empresas, v. 46, n. 1, p. 27-40, 2006. 
HALL, D. T. Careers in organization. Pacific Paradise: Goodyer, 1976. HALL, D. T. Protean careers of the $21^{\text {st }}$ century. The Academy of Management Executive, v. 10, n. 4, p. 8-16, 1996.

HENDERSON, P. A.; DE ARAÚJO FERREIRA, M.; DUTRA, J. S. As barreiras para a ascensão da mulher a posições hierárquicas: um estudo sob a óptica da gestão da diversidade no Brasil. Revista de Administração da Universidade Federal de Santa Maria, v. 9, n. 3, p. 489-505, 2016.

HIRATA, H. Gênero, patriarcado, trabalho e classe. Revista Trabalho Necessário, v. 16, n. 29, p. 14-27, 2018.

HOWES, L. M.; GOODMAN-DELAHUNTY, J. Predicting career stability and mobility: embeddedness and boundarylessness. Journal of Career Development, v. 42, n. 3, p. 244-259, 2015.

HRYNIEWICZ, L. G. C.; VIANNA, M. A. Mulheres em posição de liderança: obstáculos e expectativas de gênero em cargos gerenciais. Cadernos EBAPE.BR, Rio de Janeiro, v. 16, n. 3, p. 331-344, 2018.

INKSON, K.; DRIES, N.; ARNOLD, J. Understanding careers: metaphors of working lives. London: SAGE, 2014.

INKSON, K. et al. Boundaryless careers: bringing back boundaries. Organization Studies, v. 33, n. 3, p. 323-340, 2012.

INSTITUTO BRASILEIRO DE GEOGRAFIA E ESTATÍSTICA - IBGE. Estatísticas de gênero: indicadores sociais das mulheres no Brasil. 2018. Available at: <https://biblioteca.ibge.gov.br/visualizacao/livros/ liv101551_informativo.pdf>. Accessed on: Jan. 17, 2019.

INSTITUTO DE PESQUISA ECONÔMICA APLICADA - IPEA. ODS 5: alcançar a igualdade de gênero e empoderar todas as mulheres e meninas - o que mostra o retrato do Brasil. 2019. Available at: <http://www.ipea.gov.br/portal/index.php?option=com content\&view=article\&id=35025>. Accessed on: Jan. 17, 2019.

INSTITUTO NACIONAL DE ESTUDOSE PESQUISAS EDUCACIONAIS ANÍSIO TEIXEIRA - INEP. Mulheres são maioria na educação profissional e nos cursos de graduação. 2019. Available at: <http://inep.gov.br/ artigo/-/asset_publisher/B4AQV9zFY7Bv/content/mulheres-saomaioria-na-educacao-profissional-e-nos-cursos-de-graduacao/21206>. Accessed on: Feb. 22, 2020.

KEMP, L. J.; RICKETT, B. The lived experiences of foreign women: influences on their international working lives. Gender, Work \& Organization, v. 25, n. 4, p. 343-360, 2018.

KNIGHT, M. Race-ing, classing and gendering racialized women's participation in entrepreneurship. Gender, Work \& Organization, v. 23, n. 3, p. 310-327, 2016.

KÖLLEN, T. Diversity management: a critical review and agenda for the future. Journal of Management Inquiry, v. 28, p. 1-14, 2019.

KOSSEK, E. E.; SU, R.; WU, L. “Opting out” or "pushed out”? Integrating perspectives on women's career equality for gender inclusion and interventions. Journal of Management, v. 43, n. 1, p. 228-254, 2017.

LEUZE, K.; STRAUß, S. Why do occupations dominated by women pay less? How 'female-typical' work tasks and working-time arrangements affect the gender wage gap among higher education graduates. Work, Employment and Society, v. 30, n. 5, p. 802-820, 2016.

LIMA, G. S. et al. O teto de vidro das executivas brasileiras. Revista Pretexto, v. 14, n. 4, p. 65-80, 2014.
MACHADO, H. P. V.; GUEDES, A.; GAZOLA, S. Determinantes e dificuldades de crescimento para mulheres empreendedoras. Revista Pensamento Contemporâneo em Administração, v. 11, n. 1, p. 85-99, 2017.

MAINIERO, L. A.; GIBSON, D. E. The kaleidoscope career model revisited: how midcareer men and women diverge on authenticity, balance, and challenge. Journal of Career Development, v. 45, n. 4, p. 361-377, 2018.

MAYRHOFER, W.; MEYER, M.; STEYRER, J. Contextual issues in the study of careers. In: GUNZ, H. P.; PEIPERL, M. (Org.). Handbook of career studies. London: SAGE, 2007. p. 215-240

MCDONALD, J. Occupational segregation research: queering the conversation. Gender, Work \& Organization, v. 23, n. 1, p. 19-35, 2016.

MCKIE, L.; BIESE, I.; JYRKINEN, M. 'The best time is now!': the temporal and spatial dynamics of women opting in to self-employment. Gender, Work \& Organization, v. 20, n. 2, p. 184-196, 2013.

MENEGHETTI, F. K. O que é um ensaio-teórico?. Revista de Administração Contemporânea, v. 15, n. 2, p. 320-332, 2011.

O'NEILL, M. S.; JEPSEN, D. Women's desire for the kaleidoscope of authenticity, balance and challenge: a multi-method study of female health workers' careers. Gender, Work \& Organization, v. 26, n. 7, p. 962-982, 2019.

ORUPABO, J.; NADIM, M. Men doing women's dirty work: desegregation, immigrants and employer preferences in the cleaning industry in Norway. Gender, Work and Organization, p. 1-15, 2019. Early view.

PORTER, C.; WOO, S. E.; TAK, J. Developing and validating short form protean and boundaryless career attitudes scales. Journal of Career Assessment, v. 24, n. 1, p. 162-181, 2016.

PRASAD, P.; D'ABATE, C.; PRASAD, A. Organizational challenges at the periphery: career issues for the socially marginalized. In: GUNZ, H. P.; PEIPERL, M. (Org.). Handbook of career studies. London: SAGE, 2007. p. $169-187$

PRESTES, V. A.; GRISCI, C. L. I.; FRAGA, A. M. Lifestyles of workers in the expatriation context. Revista de Administração Mackenzie, v. 17, n. 3, p. 39-59, 2016.

RAMASWAMI, A.; CARTER, N. M.; DREHER, G. F. Expatriation and career success: a human capital perspective. Human Relations, v. 69, n. 10, p. 1959-1987, 2016.

RESSIA, S.; STRACHAN, G.; BAILEY, J. Operationalizing intersectionality: an approach to uncovering the complexity of the migrant job search in Australia. Gender, Work \& Organization, v. 24, n. 4, p. 376-397, 2017.

RIAÑO, Y. Minga biographic workshops with highly skilled migrant women: enhancing spaces of inclusion. Qualitative Research, v. 16, n. 3, p. 267-279, 2016.

RISMAN, B. J.; DAVIS, G. From sex roles to gender structure. Current Sociology, v. 61, n. 5-6, p. 733-755, 2013.

RODRIGUEZ, J. K.; SCURRY, T. Female and foreign: an intersectional exploration of the experiences of skilled migrant women in Qatar. Gender, Work \& Organization, v. 26, n. 4, p. 480-500, 2019.

ROOS, $\mathrm{H}$. In the rhythm of the global market: female expatriates and mobile careers - a case study of Indian ICT professionals on the move. Gender, Work \& Organization, v. 20, n. 2, p. 147-157, 2013. 
SANG, K. J. C.; AL-DAJANI, H.; ÖZBILGIN, M. Frayed careers of migrant female professors in British academia: an intersectional perspective. Gender, Work \& Organization, v. 20, n. 2, p. 158-171, 2013.

SANG, K. J. C.; CALVARD, T. I'm a migrant, but I'm the right sort of migrant: hegemonic masculinity, whiteness, and intersectional privilege and (dis)advantage in migratory academic careers. Gender, Work \& Organization, v. 26, n. 10, p. 1506-1525, 2019.

SCOTT, J. W. Gender: a useful category of historical analysis. The American historical review, v. 91, n. 5, p. 1053-1075, 1986.

SCOTT, J. W. Os usos e abusos do gênero. Projeto História, n. 45, p. 327-351, 2012.

SHELLER, M. Sociology after the mobilities turn. In: ADEY, P. et al. (Org.). The Routledge handbook of mobilities. London/New York: Routledge, 2014a. p. 45-54

SHELLER, M. The new mobilities paradigm for a live sociology. Current Sociology, v. 62, n. 6, p. 789-811, 2014b.

SOUZA, E. M. A teoria queer e os estudos organizacionais: revisando conceitos sobre identidade. Revista de Administração Contemporânea, v. 21, n. 3, p. 308-326, 2017.

SOUZA, E. M.; BIANCO, M. D. F.; JUNQUILHO, G. S. Contestações sobre o masculino no contexto do trabalho: estudo pós-modernista em mineradoras e siderúrgicas. Revista de Administração Contemporânea, v. 19, p. 269-287, 2015. Edição especial.

SOUZA, E. M.; CORVINO, M. D. M. F.; LOPES, B. C. Uma análise dos estudos sobre o feminino e as mulheres na área de administração: a produção científica brasileira entre 2000 a 2010. Organizações \& Sociedade, v. 20, n. 67, p. 603-621, 2013.

STOKES, A. Fashioning gender: the gendered organization of cultural work. Social Currents, v. 4, n. 6, p. 518-534, 2017.

SULLIVAN, S. E.; ARTHUR, M. B. The evolution of the boundaryless career concept: Examining physical and psychological mobility. Journal of vocational behavior, v. 69, n. 1, p. 19-29, 2006.

SULLIVAN, S. E.; BARUCH, Y. Advances in career theory and research: a critical review and agenda for future exploration. Journal of Management, v. 35, n. 6, p. 1542-1571, 2009.

SULLIVAN, S. E.; MAINIERO, L. A. Using the kaleidoscope career model to understand the changing patterns of women's careers: designing HRD programs that attract and retain women. Advances in Developing Human Resources, v. 10, n. 1, p. 32-49, 2008.

TAPIA, M.; ALBERTI, G. Unpacking the category of migrant workers in trade union research: a multi-level approach to migrant intersectionalities. Work, Employment and Society, v. 33, n. 2, p. 314-325, 2019.

TROTTER, L. J. Making a career: reproducing gender within a predominantly female profession. Gender \& Society, v. 31, n. 4, p. 503-525, 2017.

UTENG, T. P.; CRESSWELL, T. (Org.). Gendered mobilities. Aldershot: Ashgate, 2008.

WALTER, B. 'Old mobilities'? Transatlantic women from the West of Ireland 1880s-1920s. Irish Journal of Sociology, v. 23, n. 2, p. 49-68, 2015.), Porto Alegre-RS, Brazil. E-mail: rocha.oliveira@ufrgs.br

Aline Mendonça Fraga

ORCID: https://orcid.org/0000-0002-4240-464X

Ph.D. in administration from the School of Administration of the Federal University of Rio Grande do Sul (UFRGS), Porto Alegre - RS, Brazil. E-mail: alinemf.adm@gmail.com

Sidinei Rocha-de-Oliveira

ORCID: https://orcid.org/0000-0001-9139-2684

Ph.D. in administration from Universitè Pierre Mendés-France and Federal University of Rio Grande do Sul (UFRGS); Associate Professor at the Department of Administration of the Federal University of Rio Grande do Sul (UFRGS), Porto Alegre - RS, Brazil. E-mail: rocha.oliveira@ufrgs.br 